- HAMZAH

Universitas Gadjah Mada

\title{
TIMBUL TENGGELAM PERLAWANAN DALAM NOVEL GENRE DEWASA MUDA (YOUNG ADULT)
}

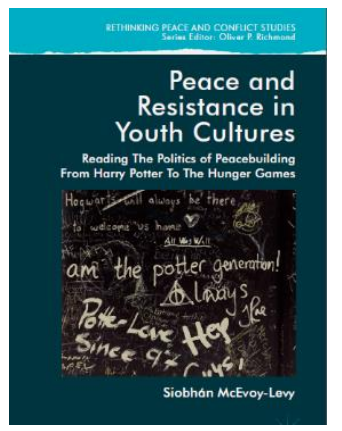

Judul Asli
Penulis
Penerbit
Tahun
ISBN

: Peace and Resistance in Youth Cultures Reading The Politics of Peacebuilding From Harry Potter To The Hunger Games

Siobhan McEvoy-Levy

: Macmillan Publishers Ltd.

: 2017

ISBN

: 978-1-137-49870-0

Dua dari tiga pandangan utama pembacaan terhadap kaum muda dapat digunakan dalam ulasan ini. Tiga pandangan tersebut adalah kaum muda dalam perubahan, sebagai agensi, dan budaya itu sendiri (White \& Naafs 2012). Dua pandangan dominan yang dapat disorot lebih adalah bagaimana kaum muda terlibat dalam transisi perubahan dan bergerak sebagai agensi. Dengan menyorot dua pandangan tersebut, secara sendirinya budaya kaum muda an sich mampu terbedah.

Jika kita membicarakan mengenai peran kaum muda dalam transisi perubahan, tidak akan asing dari dunia perlawanan. Di masa-masa kiwari, kaum muda yang melawan bukan lagi menjadi gambar yang asing di benak peradaban. Meski pun begitu, imaji-imaji aksi yang dipenuhi kaum muda tidak pula membangkitkan diskusi mendalam terkait bentuk-bentuk perlawanan dan teori-teori perubahan yang dilakukan oleh kaum muda. Tidak terbantahkan lagi, pada risetriset perlawanan kaum muda, tumbuh harapan bahwa perlawanan akan mengantarkan pada merdesanya sebuah komunitas.

Perlawanan sendiri sering kali diromantisir; dalam formulasi tertentu, perlawanan dianggap sebagai tenaga mentah yang perlu dijinakkan dan didisiplinkan ke dalam tapak-tapak kemenjadian peradaban demokratis yang bertanggung jawab (dalam kasus negara), dan pendisiplinan menjadi kependudukan demokratis dewasa yang manut dan bertanggung jawab (dalam kasus kaum muda). Ada praanggapan bahwa teori perlawanan ajeg kontras dengan teori reproduksi -yang mana peluang transformasi sosial dilumpuhkan oleh kuasa struktural yang langgeng dan tidak terkalahkan menciptakan ketidaksetaraan dari generasi ke generasi. 
Tuck dan Young (2012) menekankan bahwa perlawanan pemuda menawarkan bentuk-bentuk lain dari kebertahanan, peluang dekolonial, agnostisisme dengan progres, dan keinginan untuk mempertahankan harga diri yang akan memperkaya perbincangan mengenai teori perubahan yang selama ini remeh. Kita bisa menuding perkembangan psikologi yang menormalisasi perlawanan alias pemberontakan kaum muda sebagai sebuah fase ergo yang tidak mengakui pilihan-pilihan masuk akal kaum muda.

Buku yang berjudul 'Peace and Resistance in Youth Cultures: Reading The Politics of Peacebuilding from Harry Potter to The Hunger Games' mencoba untuk menyulam ontologi konflik dan penciptaan perdamaian ke dalam studi perdamaian. Perlawanan kaum muda sedikit banyak mengambil peran aksiologis dari studi ini; Siobhan McEvoy-Levy menggunakan novel Harry Potter dan The Hunger Games sebagai objek material yang dibedah produksi kulturalnya untuk memahami persoalan konflik, perdamaian, dan perlawanan. Studi ini mengombinasikan pandangan-pandangan dari teori-teori post-struktural, postkolonial, feminis, dan studi konflik serta perdamaian untuk meng-analisa tema-tema kasusastraan, kegunaan politik, dan dampak kultural dari dua buku laris ini.

Ada setidaknya tiga pertanyaan yang diajukan oleh buku ini. Pertama, bagaimana budaya populer relevan untuk riset perdamaian. Kedua, bagaimana periset studi perdamaian meriset dalam kerangka kerja budaya populer. Ketiga, apa yang bisa didapat dengan mengintegrasikan lensa studi kepemudaan dalam riset ini. Pemilihan objek material yang berupa karya sastra sendiri -lebih spesifiknya, fiksi novel dewasa muda, tidak lepas dari fenomena kultural belakangan ini. Tematema perlawanan yang tidak lagi subtil mampu mengekspresikan dan membuat politik perdamaiannya sendiri melalui apa yang didefinisikan Vivienne Jabri; "sebuah kapasitas untuk melawan kekerasan dan perjuangan untuk tata sosial yang adil."

Fokus yang coba dihantarkan oleh buku ini adalah eksperimen ilmiah-kritis untuk berkontribusi pada wacana anti militerisme, nirkekerasan, dan pasifisme dalam budaya populer. Dalam konteks kekaryaan Harry Potter dan The Hunger Games, simbol-simbol militerisme bukan hal yang bisa dilepas begitu saja. Simbolsimbol militer, representasi, pembicaraan, dan citranya sekarang mendominasi lanskap politik dan kebudayaan di Amerika Serikat maupun di banyak negara lainnya. Tidak heran, militer menjadi mitos yang digunakan dalam dunia hiburan; McEvoylevy menyebutnya sebagai militainment. Militainment sendiri membantu untuk mengonstruksi identitas para penduduk sebuah negara dalam relasinya terhadap perang, dan turut menormalisasi perang sebagai alat kebijakan ke luar negeri.

Riset interpretatif ini menggunakan analisis wacana dan observasi partisipan daring untuk menawarkan baik pandangan teoritis maupun temuan empiris yang mengungkapkan makna berlapis dari perdamaian beserta tegangan dan kontradiksinya. Hal ini sebagaimana yang tampak melalui budaya muda dan dalam wacana politik serta media -dalam hal ini, sastra dewasa muda. Sastra dewasa muda mempromosikan hubungan intergenerasi dan memiliki fungsi sosialisasi. Dalam membentuk akal awam yang baru mengenai politik, sastra dewasa muda juga membentuk 'capaian/ramalan yang dijalani sendiri' dalam pembangunan perdamaian di kalangan muda.

Untuk ringkasnya, studi ini mencoba menjelaskan makna dari perdamaian yang diproduksi oleh para kawula, utamanya kawula muda -membaca, menonton, mengkritik, menulis tentang, bertindak atas, membuat, memakai, dan memperdebatkan Harry Potter dan The Hunger 
Games -dalam batasan-batasan tata aturan internasional yang neoliberal. Setidaknya, ada delapan argumen utama yang dapat dikritisi dibeberkan dalam buku ini.

Pertama, sastra dan film dewasa muda yang dimaksud memfokuskan pada 'tentara anak-anak' dan debat etis mengenai kekerasan politis, menggugat wacana arus utama mengenai perang dan militerisasi dengan diam-diam. Kedua, membaca karya-karya ini menyingkap wacana-wacana nirkekerasan, empati relasional, dan 'perdamaian positif' (sebagai hiburan) yang beriringan dengan wacana militainment dan bagian-bagian yang termiliterisasi dari hidup keseharian. Ketiga, ketika bersinggungan dengan produksi budaya penggemar, wacana perdamaian dalam karya-karya ini kehilangan beberapa aspek, berubah, dan/atau dipraktekkan. Keempat, menempel pada struktur kekerasan global dan lokal, kegiatan konsumsi karya-karya ini tidak dapat dilepaskan dari praktik ketidakadilan dan manipulasi. Kelima, membaca kebudayaan populer untuk perdamaian membutuhkan toleransi atas ambiguitas. Keenam, fenomena konsumsi sastra dewasa muda menunjukkan bahwa anak muda mampu menjadi agen perdamaian dan menggambarkan bagaimana mereka memengaruhi kehidupan sosial di luar dirinya. Ketujuh, membaca perdamaian dalam budaya populer membutuhkan refleksi atas tindakan membaca itu sendiri. Terakhir, proyek untuk mempopulerkan perihal hubungan internasional dan perdamaian, membutuhkan penyesuaian selera terhadap target yang diinginkan.

Mari berbicara mengenai aspek kebudayaan dari novel dewasa muda ini; kebudayaan melanggengkan solidaritas dan identitas melalui pengalaman bersama (shared). Kebudayaan juga memproduksi dan melanggengkan kuasa. Kebudayaan populer tidak hanya mempertontonkan kekerasan melalui gambar dan cerita, ia dapat juga membikin kekerasan -langsung, struktural, dan kultural- melalui narasi, desain, produksi, dan pola konsumsi. Para akademisi, termasuk Shapiro, Weber, Weldes, Dittmer, dan lainnya telah menunjukkan bahwa teks populer, produk, dan praktik adalah kendaraan penting untuk beberapa ide dan kepercayaan. Di mana hal tersebut menjadi hegemonik, terintegrasi dalam keseharian, natural, dan tak terbantahkan sebagai nyata dan tak dapat dihindari. Foucault (1979) berpendapat bahwa, "dalam setiap kelompok masyarakat, produksi wacana pada satu titik dikontrol, dipilih, diorganisir, dan diredistribusi melalui beberapa tingkat prosedur, yang mana tujuannya adalah untuk membatasi kekuasaannya dan bahayanya." Giorgio Agamben (2009) lain lagi; Agamben mengajukan konsep apparatus, "apapun yang mampu menangkap, mengarahkan, memutuskan, mencegat, mencontoh, mengontrol, atau mengamankan gestur, perilaku, opini, atau diskursus pada manusia hidup." Setiap apparatus mengisyaratkan sebuah proses objektifikasi, yang tanpanya tidak mampu berfungsi sebagai sebuah aparatus pemerintahan, tapi hanya tereduksi menjadi sekadar penggunaan kekerasan.

Membicarakan sastra tidak akan lepas dari intertekstualitas pula. Heathershaw berargumen bahwa 'intertekstualitas dalam penciptaan perdamaian yang intens membikin bayangan tentang bagaimana tindakan militer digambarkan sebagai tindakan humanitarian, dan intervensi humanitarian membutuhkan tindakan militer. Interteks sastra militainment mengizinkan militer menjadi simbol yang menjadikan 'setiap jalan jika diperlukan', dalam arti kekerasan dinafikan sedemikian rupa dengan justifikasi tujuan. De Certeau mengklaim, pembaca adalah pemburu, di mana mereka mampu mengambil dan menginterpretasikan apa yang mereka baca, tanpa otoritas kritik dan penyuntingan, dan mengubahnya menjadi modal dan atau nutrisi. Ide-ide Anzaldua 
mengenai kesadaran mestiza dan nepantla/nepantleras menyediakan rangka kerja alternatif terhadap konfigurasi biner kita dan mereka. Membaca adalah bagian dari pembentukan identitas dalam pemikian Anzaldua, mengizinkan baik empati maupun reidentifikasi.

Pemuda merupakan manusia dan isu kebijakan/politis secara simultan. Ada empat perspektif teoritis utama dalam ilmu sosial studi kepemudaan kontemporer: satu, fokus pada transisi developmental. Dua, fokus pada konstruksi sosial pada masa kecil yang menekankan pada agensi anak muda dan kebudayaan muda. Tiga, fokus pada generasi sosial dan penekanan pada peran transformasi sosial dari generasi muda yang spesifik (nasional dan transnasional). Empat, pandangan hibrid yang menggabungkan ekologi sosial dan kehidupan pemuda. Kita perlu menjadi kritis terhadap diri sendiri dan reflektif mengenai bagaimana studi kepemudaan mengharuskan 'ikut serta dalam sebuah tindakan menjajah kekuasaan dengan mengendalikan representasi 'Sang Liyan' dan memproduksi sebuah imaji spesifik dan menjenuhkan secara politis atas dunia,' sebagaimana yang ditulis Dunn.

Penulis buku ini berargumen bahwa akar dari pembangunan perdamaian liberal dapat ditelusuri kepada keterlibatan/ keruwetan historis dan kultural wacanawacana mengenai diri dan relasinya kepada Yang Liyan. Pemuda, sebagai sebuah tubuh politis, sebuah target dari kebijakan sosial, metafor, dan simbol, telah menjadi jantung bagi proyek pembangunan dan perdamaian liberal.

Keterlibatan dalam produksi budaya ini dilakukan dalam basis komunitas penggemar. Komunitas penggemar, dengan dorongan ideologis membentuk apa yang disebut dengan aktivisme penggemar. Aktivisme penggemar adalah sebuah ruang di mana para pemburu yang mana mencoleng dari sektor hiburan korporasi dan menjadikannya 'profan' (dalam terma Agamben) yang pada mulanya hanya menjadi properti elit media, intelektual, ekonomi. Dua bentuk aktivisme penggemar menerangkan dua bentuk yang mungkin dari ruang pembangunan perdamaian pascaliberal: satu, terorganisir, berdasarkan norma yang sudah ada; lainnya, tidak terorganisir, berdasarkan subjektivitas dan tujuan agonistis. Keduanya melibatkan kerja-kerja di tapal batas; lokal-global, realitas-fiksi, daring-luring, dengan kolaborasi tua-muda. Sebuah jembatan budaya pop menghubungkan bentuk pluralis dan post-struktural membayangkan /mewujudkan perdamaian. Anzaldua mengonseptualisasikan aktivisme sebagai sebuah bentuk kekuasaan yang berakar pada ide dan keputusan untuk menjelajah melampaui ruang nyaman seseorang. Aktivisme penggemar mengukuhkan kembali bahwa komunitas transnasional atas ide-ide dan nilai-nilai bersama adalah mungkin. Aktvisme penggemar yang dipelajari penulis buku ini adalah bagian dari budaya kesenangan yang menubuh yang mana melibatkan keinginan untuk damai dalam berbagai bentuk. Kita dapat menimbang bagaimana kuasa neoliberal ini ditantang melalui apa yang disebut Agamben (2009) sebagai 'penghinaan atas apparatus'.

Buku ini ditulis dengan cukup komprehensif dan lengkap, bahkan ketika bersandar dengan dua objek material saja. Kemungkinan riset-riset ke depan mengenai epistemologi budaya populer dalam studi kepemudaan semakin terbuka dengan adanya karya-karya seperti ini. Hanya saja, sebagaimana teks ilmiah kritik sastra dan teori kritis, kerancuan istilah bisa kapan saja hadir dan membingungkan pembaca awam. Dalam konteks studi kepemudaan, barangkali studi ini mampu memberikan pertimbangan ontologis atas transformasi ideologis dalam gerak kaum muda. 


\section{DAFTAR PUSTAKA}

Agamben, Giorgio. 2009. "What is an apparatus?" and other essays. Amerika Serikat: Stanford University Press.

Foucault, Michel, Arnold I. Davidson, and Graham Burchell. 2008. "The birth of biopolitics: lectures at the Collège de France, 1978-1979.” Springer.

Naafs, Suzanne, and Ben White. 2012. "Intermediate generations: reflect- ions on Indonesian youth studies." The Asia Pacific Journal of Anthropology 13.1: 3-20.

Tuck, Eve, and K. Wayne Yang, eds. 2013. Youth resistance research and theories of change. London: Routledge. 